\title{
Biological Contamination
}

National Cancer Institute

\section{Source}

National Cancer Institute. Biological Contamination. NCI Thesaurus. Code C92054.

The undesirable presence of living org anisms such as bacteria, fungi, or viruses or their products (enzymes or toxins). 